\title{
Principal Component Analysis in Rainfed Green Gram Genotypes [Vigna radiata (L.) Wilczek]
}

\author{
Champa Lal Khatik* \\ Plant Breeding and Genetics, Agricultural Research Station, Fatehpur-Shekhawati, \\ Sikar, Rajasthan, (SKN Agriculture University, Jobner), India \\ *Corresponding author
}

\section{A B S T R A C T}

\section{Keywords \\ principal component analysis, green gram, genotypes}

\section{Article Info}

Accepted: 10 April 2020 Available Online: 10 May 2020
The present investigation entitled "Principal component analysis in rainfed green gram genotypes [Vigna radiata (L.) Wilczek]" was carried out to determine the relationship and genetic diversity among 16 green gram genotypes using principal component analysis for various characters during Kharif, 2019 at Agricultural Research Station, Fatehpur Shekhawati, Sikar (Rajasthan) under rainfed conduction. Principal component analysis (PCA) depicted that three components (PC1 to PC3) accounted for about more than $90 \%$ of the total variation for different characters. Out of total principal components retained V1, V2, V3 and V4 with values of $39.15 \%, 25.29 \%, 15.72 \%$ and 10.79 respectively. PCA based clustering showed that genotypes fall in to five different clusters showed genetic diversity between different genotypes. The Genotypes MSJ-118 and RMG-1094 which represents the mono genotypic cluster signifies that it could be the most diverse from other genotypes and it would be the suitable candidate for hybridization with genotypes present in other clusters to tailor the agriculturally important characters and ultimately to enhance the seed yield in green gram. Thus the results of principal component analysis revealed, wide genetic variability exists in these green gram genotypes. Hence these could be utilized as parental material in future breeding programme for green gram improvement.

\section{Introduction}

Green gram (Vigna radiata (L.) Wilczek) is one of the important pulse crops in arid region because of its short growth duration, adaptation to low water requirement and low soil fertility (Raturi et al., 2015). It is favored for consumption due to its easy digestibility and low production of flatulence.
Pulses are extensively grown in tropical regions of the world as a major protein rich crop bringing considerable improvement in human diet (Muthuswamy et al., 2019 and Rahim et al., 2010).

Average protein content in the seed is around 24 per cent. The protein is comparatively rich in the amino acid lysine but predominantly 
deficient in cereal grains (Baskaran et al., 2009 Garg et al., 2017 and Dhanajay et al., 2009). Presently, the yield of green gram is well below the optimum level compare to other pulses. Green gram (Vigna radiata (L.) Wilczek) is one of the chief pulse crops grown in India after chickpea and pigeon pea. In India, green gram is cultivated in 4.26 million ha with a production of 2.01 million tonnes and productivity of $472 \mathrm{~kg} / \mathrm{ha}$ (AICRP on MULLaRP, 2018-19).

The average yield of green gram is very low not only in India but in entire tropical and sub-tropical Asia (Pratap et al., 2012 and Kumar et al., 2005).Grouping of green gram genotypes based on genetic divergence for different characters will enable breeders for the better selection of parents during hybridization (Tripathi,2019).

In plant breeding, genetic diversity plays an important role because hybrids between genetically diverse parents manifest greater heterosis than those between more closely related parents (Mahalingam et al., 2018). Some appropriate methods viz., factor analysis, cluster analysis and PCA helps in parental selection and genetic diversity identification. Recently PCA has been cited by various authors for the reduction of multivariate data into a few artificial varieties which can be further used for classifying material. The main objective of this study was to assess the potential genetic diversity and correlation by using cluster analysis-PCAbased methods for selection of parents in hybridization programme to obtain desirable segregants in advanced generation and to study the genetic parameters attributing to yield. The aim of present study was to identify better combinations as selection criteria for developing high yielding fine green gram genotypes. Such type of findings may help green gram breeders and it could provide new opportunities for promoting the production of green gram with better yield.

\section{Materials and Methods}

The present investigation entitled "Principal component analysis in rainfed green gram genotypes [Vigna radiata (L.) Wilczek]" was under taken to study the different parameters of divergence. Sixteen genotypes of green gram were sown in randomized block design with three replications during Kharif, 2019 at research farm of Agricultural Research Station, Fatehpur-Shekhawati, Sikar (Rajasthan) under rainfed conduction. These genotypes of green gram were obtained from All India Coordinated Research Project on MULLaRP, RARI, Durgapur (Jaipur) is as under:

\begin{tabular}{|l|l|l|l|}
\hline 1.RMG-492 & 5. RMG-1087 & 9. RMG-1134 & 13. RMG-1147 \\
\hline 2.RMG-975 & 6.RMG-1094 & 10. RMG-1137 & 14.RMG-1148 \\
\hline 3.IPM-02-3 & 7.RMG-1098 & 11.RMG-1138 & 15.RMG-1152 \\
\hline 4.MSJ-118 & 8.RMG-1132 & 12.RMG-1139 & 16.RMG-1154 \\
\hline
\end{tabular}

Each genotype was given in a four row plot of $4 \mathrm{~m}$ length with a spacing of $30 \mathrm{~cm}$ between rows and $10 \mathrm{~cm}$ between plants. Ten plants were selected at random from each plot and data were recorded on 8 characters viz., plant height, pod length, number of seeds per pod, Test weight, seed yield per plot and seed yield per hectors whereas for days to $50 \%$ flowering and days to maturity data were recorded on whole plot basis.

The data so obtained were subjected to analysis of variance and genetic divergence using cluster analysis-PCA-based methods. 


\section{Results and Discussion}

Principal component analysis (PCA) reflects the importance of the largest contributor to the total variation at each axis of differentiation (Sharma, 1998). To understand variable independence and balanced weighting of characters, principal component analysis (PCA) was done to estimate effective contribution of different characters on the basis of respective variation (Table-1).Three principal components (PC1 to PC3) which were extracted from the original data and having latent roots greater than one accounting more than $90 \%$ of the total variation. Suggesting these principal component scores might be used to summarize the original eight variables in any further analysis of the data. Out of total principal components retained V1, V2, V3 and V4 with values of $39.15 \%, 25.29 \%$,
$15.72 \%$ and 10.79 (Table-1) respectively contributed more to the total variation. According to Chahal et al., (2002) and Hadavani et al., (2018) characters with lower absolute value closer to zero influence the clustering less than those with largest absolute value closer to unity within the first principal component.

Accordingly, the first principal component (V1) had positive component loading from days to $50 \%$ flowering (0.528), days to maturity (0.270), pod length (0.191) and no. of seeds per pod (0.449) and negative loading for plant height $(-0.428)$ followed by seed yield per plot $(-0.353)$,test weight $(-0.014)$ and seed yield $\mathrm{kg}$ per hectare (Table-1). The characters which load positively or negatively contributed more to the diversity and they were the ones that most differentiated the clusters.

Table.1 Eigenvectors and eigene values of principal components for 8 characters of green gram genotypes

\begin{tabular}{|l|c|c|c|c|}
\hline Characters & $\begin{array}{c}\text { 1 Vector } \\
\text { (PC1) }\end{array}$ & $\begin{array}{c}\text { 2 Vector } \\
\text { (PC2) }\end{array}$ & $\begin{array}{c}\text { 3 Vector } \\
\text { (PC3) }\end{array}$ & $\begin{array}{c}\text { 4 Vector } \\
\text { (PC4) }\end{array}$ \\
\hline Eigene Value (Root) & 3.13230 & 2.02368 & 1.25790 & 0.86395 \\
\hline \% Var. Exp. & 39.15380 & 25.29599 & 15.72374 & 10.79940 \\
\hline Cum. Var. Exp. & 39.15380 & 64.44978 & 80.17352 & 90.97292 \\
\hline 1. D50\%F & 0.52870 & 0.06268 & 0.09757 & 0.17231 \\
\hline 2. DM & 0.27085 & 0.28276 & 0.64504 & -0.06027 \\
\hline 3. PH (cm) & -0.42871 & 0.05651 & 0.40266 & -0.27115 \\
\hline 4. PL(cm) & 0.19186 & -0.57640 & -0.06372 & 0.22409 \\
\hline 5. No. of S/P & 0.44940 & 0.24967 & 0.09027 & 0.34440 \\
\hline 6. SY/Plot (g) & -0.35346 & -0.20077 & 0.14473 & 0.75830 \\
\hline 7. TW(g) & -0.01408 & -0.45500 & 0.61164 & -0.03680 \\
\hline 8. SY(kg/ha) & -0.31530 & 0.52059 & 0.07075 & 0.38464 \\
\hline
\end{tabular}


Table.2 The PCA scores of 16 genotypes of green gram

\begin{tabular}{|c|c|c|c|}
\hline Genotypes & $\begin{array}{c}\text { PCA I } \\
\text { (X Vector) }\end{array}$ & $\begin{array}{c}\text { PCA II } \\
\text { (Y Vector) }\end{array}$ & $\begin{array}{c}\text { PCA III } \\
\text { (Z Vector) }\end{array}$ \\
\hline $\mathbf{1}$ | RMG-492 & 22.846 & -10.636 & 54.930 \\
\hline $\mathbf{2}$ | RMG-975 & 22.294 & -12.615 & 56.403 \\
\hline 3 | IPM-02-3 & 23.467 & -13.328 & 58.283 \\
\hline $\mathbf{4}$ | MSJ-118 & 24.342 & -13.224 & 58.531 \\
\hline $\mathbf{5}$ | RMG-1087 & 22.005 & -13.213 & 57.716 \\
\hline $\mathbf{6}$ | RMG-1094 & 25.162 & -14.678 & 55.080 \\
\hline $\mathbf{7}$ | RMG-1098 & 19.406 & -12.754 & 55.639 \\
\hline $\mathbf{8}$ | RMG-1132 & 17.980 & -15.340 & 60.584 \\
\hline 9 | RMG-1134 & 19.831 & -11.219 & 56.220 \\
\hline $\mathbf{1 0}$ | RMG-1137 & 20.192 & -13.971 & 56.584 \\
\hline $\mathbf{1 1}$ | RMG-1138 & 19.386 & -13.077 & 56.551 \\
\hline $\mathbf{1 2}$ | RMG-1139 & 20.947 & -15.390 & 58.473 \\
\hline $\mathbf{1 3}$ | RMG-1147 & 18.470 & -16.134 & 60.325 \\
\hline $\mathbf{1 4}$ | RMG-1148 & 22.782 & -14.661 & 59.039 \\
\hline $\mathbf{1 5}$ | RMG-1152 & 23.823 & -11.891 & 57.842 \\
\hline $\mathbf{1 6}$ | RMG-1154 & 23.619 & -12.379 & 58.908 \\
\hline
\end{tabular}

Table.3 K means clustering for 8 characters of green gram genotypes

\begin{tabular}{|l|c|c|c|c|c|c|c|c|}
\hline \multicolumn{10}{|c|}{ K Mean Clustering } \\
\hline Characters & D50\%F & DM & PH & PL & No. of & SY/ & TW & SY \\
& & & $(\mathrm{cm})$ & $(\mathrm{cm})$ & S/P & Plot $(\mathrm{g})$ & $(\mathrm{g})$ & $(\mathrm{kg} / \mathrm{ha})$ \\
\hline $\mathbf{1}$ Cluster & 40.500 & 61.667 & 41.875 & 7.708 & 10.667 & 217.917 & 32.800 & 605.323 \\
\hline $\mathbf{2}$ Cluster & 42.667 & 61.167 & 35.000 & 7.867 & 11.833 & 234.167 & 32.667 & 650.458 \\
\hline 3 Cluster & 37.333 & 59.833 & 44.208 & 7.658 & 10.833 & 280.000 & 30.758 & 777.774 \\
\hline $\mathbf{4}$ Cluster & 38.222 & 60.889 & 45.222 & 8.011 & 10.611 & 368.889 & 33.944 & 1020.572 \\
\hline $\mathbf{5}$ Cluster & 41.778 & 62.667 & 41.389 & 7.533 & 11.722 & 222.778 & 31.356 & 618.826 \\
\hline
\end{tabular}




\section{Grouyrikhin SS Cluster MIembers --->}

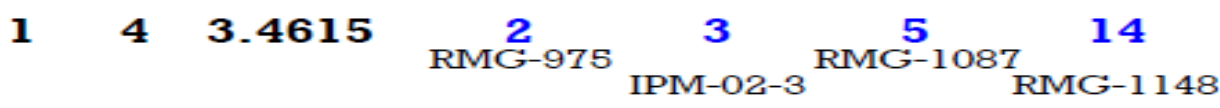

$\begin{array}{lllcc}2 & 2 & 1.3939 & 4 & 6 \\ & & & 6 \\ \text { RMJ } 118-1094\end{array}$

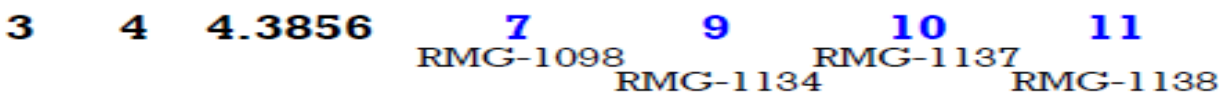

$4 \quad 3 \quad 5.4554 \quad \underset{\text { RMG-1132 }}{8} 12 \underset{\text { RMG-1 } 139}{\text { RMG-1147 }}$

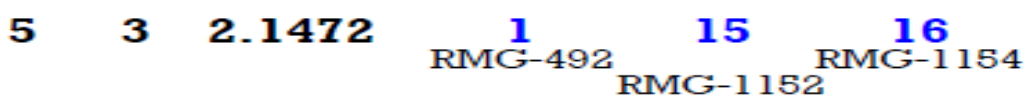

Figure.1 Clustering of green gram genotypes by K means clustering method

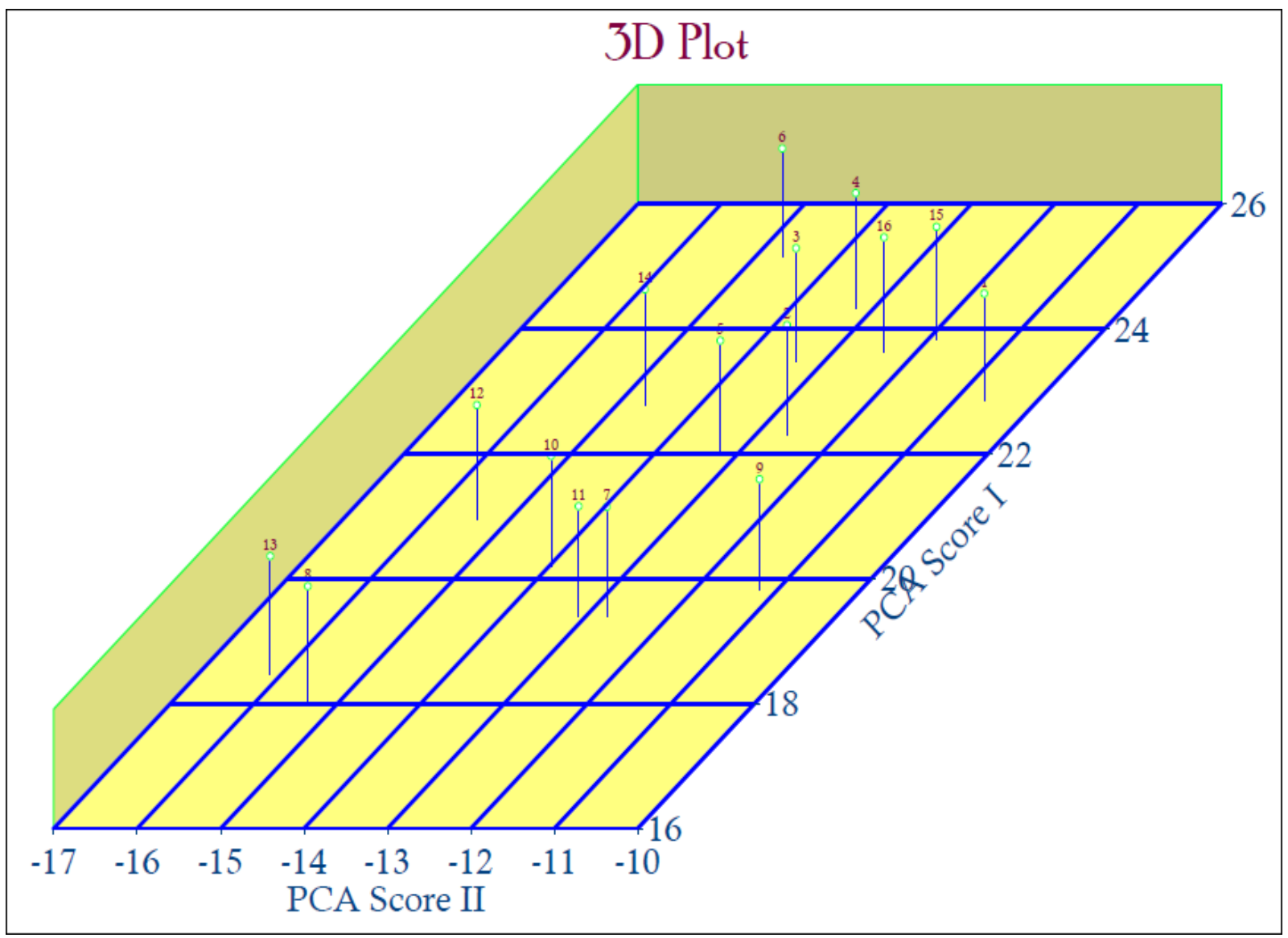

Figure.2 Three dimensional graph showing relative position of green gram genotypes based on PCA scores 
Hence, the major contributing characters for the diversity in the second principal component (V2) were days to flowering, days to maturity, plant height, no. of seeds per plant and seed yield $\mathrm{kg}$ per hectare $(0.062$, $0.282,0.056,0.249$ and 0.520 ) while pod length, seed yield per plot and test weight ($0.576,-0.200$ and -0.455$)$. Only pod length (0.063 ) load negative contributed and other characters positive contributed load for third principal component (V3).

Similarly the characters days to flowering, pod length, no. of seeds per pod, seed yield per plot and seed yield $\mathrm{kg}$ per hectare $(0.172$, $0.224, \quad 0.344,0.758,0.384$ ) which load positively while days to maturity, plant height and test weight $(-0.060,-0.271$ and -0.036$)$ negatively in fourth principal component (V4) contributed more to the diversity and they were the ones that most differentiated the clusters. Similar results were obtained in finding of Mahalingam et al., (2020) and Thippani et al., (2017).

The PCA scores for 16 genotypes in the first three principal components with eigen value more than one were computed and presented in Table-2. The PCA scores for 16 genotypes plotted in 3D (PCA I as X axis, PCA II as Y axis and PCA III as $\mathrm{Z}$ axis) scatter diagram (Fig.-2).

On the PCA based clustering, 16 genotypes were grouped into 5 clusters in which maximum number of genotypes were fall in cluster 1 and 3 (4 genotypes) followed by cluster 4 and 5 (3 genotypes), whereas minimum number of genotypes were in cluster 2 (2 genotypes) (Table-3 and Figure1). On the basis of PCA, the maximum cluster distance was obtained for cluster 4 (5.455) followed by cluster 3 (4.385), cluster 1(3.461), cluster 5 (2.147) while minimum cluster distance was obtained for cluster 2 (1.393).
These suggest that genotypes belonging to clusters separated by high statistical distance should be used in hybridization programme for obtaining a wide spectrum of variation among the segregants. Similar results were obtained in finding of Jakhar and Kumar, 2018 and Thippani et al., 2017.

There is significant genetic variability among tested genotypes that indicates the presence of excellent opportunities to bring about improvement through wide hybridization by crossing genotypes with high genetic distance. The information obtained from this study can be used to plan crosses and maximized the use of genetic diversity and expression of heterosis. Hence these could be utilized as parental material in future breeding programme for green gram improvement.

\section{References}

AICRP on MULLarp, 2019. Project Coordinator Report- (2018-19) All India Coordinated Research Project on MULLaRP, ICAR- Indian Institute of Pulses Research, Kanpur-208204, Uttar Pradesh, India, Pp 35-39.

Baskaran, L., Sundararmoorthy, P., Chidambaram, A.L.A. and Ganesh,. K.S. 2009. Growth and physiological activity of green gram (Vigna radiata (L.) Wilczek) under effluent stress. Bot. Res. Int., 2: 107-114.

Chahal GS, Gosal SS, 2002.Principles and Procedures of Plant Breeding: Biotechnological and Conventional Approaches. Alpha Science International: 604.

Dhananjay, Ramakant, Singh, B. N. and Singh, G.2009. Studies on genetic variability, correlations and path coefficients analysis in mung bean. Crop Res. Hisar. 38(1/3): 176-178.

Garg, G. K., Verma, P. K. and Kesh, H. 2017. Genetic Variability, Correlation and 
Path Analysis in Greengram [Vigna radiata (L.) Wilczek]. Int. J. Curr. Microbiol. App. Sci., 6(11): 2166-2173.

Hadavani JK, Mehta DR, Ansodariya SN and Gadhiya KK,2018.Principal component analysis and cluster analysis in Indian bean (Lablab purpureus L.).International Journal of Chemical Studies, 6(4): 1448-1452.

Jakhar, N.K. and Kumar,A.,2018. Principal component analysis and character association for yield components in greengram [Vigna radiata $(\mathrm{L}$.$) Wilczek]$ genotypes. Journal of Pharmacognosy and Phytochemistry, 7(2): 3665-3669.

Kumar,U., S.P.Singh and Vikas 2005. Variability and character association in mungbean. (Vigna radiata (L.) Wilczek). New Agriculturist, 16 (1, 2): 23-28.

Mahalingam A, Manivannan N, Ragul S and Lakshmi Narayanan S, 2018. Genetic divergence among greengram (Vigna radiata (L.) Wilczek) germplasm collections. Electronic Journal of Plant Breeding, 9 (1) : 350 - 354.

Mahalingam A, Manivannan N, Bharathi Kumar K., Ramakrishnan P. and Vadivel K.,2020. Character association and principal component analysis for seed yield and its contributing characters in greengram (Vigna radiata (L.) Wilczek). Electronic Journal of Plant Breeding, 11(1): 259-262.

Muthuswamy, A., Jamunarani, M. and
Ramakrishnan, P. 2019.Genetic Variability, Character Association and Path Analysis Studies in Green Gram (Vigna radiata (L.) Wilczek). Int.J.Curr.Microbiol.App.Sci., $\quad$ 8(4): 1136-1146.

Pratap, A., Gupta., D.S. and Rajan., N. 2012.Breeding Indian Field Crops. Agro bios Publishers, New Delhi, India. $\mathrm{p}$ 208-227.

Rahim, M. A., Mia, A. A., Mahmud, F., Zeba, N. and Afrin, K. S. 2010. Genetic variability, character association and genetic divergence in mungbean (Vigna radiata (L.) Wilczek). Plant Omics. 3(1): 1-6.

Raturi, A., Singh, S. K., Sharma, V. and Pathak, R. 2015. Genetic variability, heritability, genetic advance and path analysis in Greengram [Vigna radiata (L.) Wilczek]. Legume Res., 38 (2): 157-163.

Sharma JR,1998. Statistical and biometrical techniques in plant breeding. New Age International, New Delhi: 432.

Thippani S, Eshwari KB, Bhave MHV,2017. Principal component analysis for yield components in Greengram Accessions (Vigna radiata L.). Int. J Pure App. Biosci.; 5(4):246-253.

Tripathi, A.K. 2019. Feeling the Pulse: Towards Production Expansion of Pulses in India. Journal of Asian and African Studies, 54(6):894-912.

\section{How to cite this article:}

Champa Lal Khatik. 2020. Principal Component Analysis in Rainfed Green Gram Genotypes [Vigna radiata (L.) Wilczek]. Int.J.Curr.Microbiol.App.Sci. 9(05): 1315-1321. doi: https://doi.org/10.20546/ijcmas.2020.905.146 